\title{
EFFECTIVENESS OF GUIDED DISCOVERY BASED THERMOCHEMISTRY MODULE TO TRAIN CRITICAL THINKING SKILLS BASED ON GENDER DIFFERENCES
}

\author{
Andini Desikasari Nuraisyah ${ }^{\mathbf{1}^{*}}$, Sulistyo Saputro ${ }^{1}$ and Endang Susilowati ${ }^{1}$ \\ ${ }^{1}$ Chemistry Education, Postgraduate Program, Faculty of Teacher and Training, Universitas \\ Sebelas Maret, Jalan Ir. Sutami No. 36A, Surakarta, 57122, Indonesia \\ ${ }^{\star}$ E-mail: andini.desikasari@gmail.com
}

Received: 15 April 2020; Accepted: 25 June 2020; Published: 30 June 2020

\begin{abstract}
Critical thinking skills are important competencies that need to be developed in chemistry learning. This study aimed to determine the effectiveness of the guided discovery-based thermochemistry module in developing critical thinking skills based on gender differences. The subject of this research was 76 females and 20 males of class XI Mathematics and Nature Science from three high schools in Ponorogo, Indonesia. This study used one school for each category, namely high, medium, and low. The research method used a quasi-experimental design with one group pretest-posttest. The data analysis technique used T-test with SPSS 21 software. The result showed that the average increase in student scores or normality gain score (n-gain) was 0.5050 to 0.6362 , which means students' critical thinking skills improved after the implementation of guided discovery-based thermochemistry modules. T-test result in high category schools obtained T count $>\mathrm{T}$ table $(2.142>2.032)$, which showed that there are significant differences between the critical thinking skills of female and male students. Meanwhile, T count and T table in medium category school were 1.353 and 2.034 , respectively. $T$ count and T table in low category school respectively 1.106 and 2.068. Analysis of T-test results in medium and low school categories can be written $-\mathrm{T}$ table $<\mathrm{T}$ count $<\mathrm{T}$ table, is means there is no significant differences between the critical thinking skills of female and male students. Thus, guided discovery-based thermochemistry modules are effectively applied to high, medium and low school categories.
\end{abstract}

Keywords: module, thermochemistry, guided discovery, critical thinking, gender

DOI: http://doi.org/10.15575/jtk.v5i1.8149 
Effectiveness of Guided Discovery Based Thermochemistry Module to Train Critical Thinking Skills Based on Gender Differences

\section{INTRODUCTION}

Critical thinking is one of the important competencies in $21^{\text {st }}$ century learning (Brown, 2015; Changwong. $21^{\text {st }}$ Century learning emphasizes student-centered learning, which requires innovative thinking skills such as critical thinking (Vong and Kaewurai, 2017). Learning to think critically is a very desirable goal in the education system (Tiruneh et al., 2017).

Critical thinking is very important for students because it allows them to solve problems in difficult situations. Besides that critical thinking also trains students to communicate effectively and accurately. Critical thinking will encourage students to think deeper and be able to solve problems in school or in the context of everyday life (Jacob, 2012). Everyone must have critical thinking skills so they can analyze and compare information and build their arguments.

Critical thinking is an active and skilled intellectual process in conceptualizing, applying, analyzing, synthesizing, and evaluating information obtained through observing, reflecting, considering, or communicating (Moore and Parker, 2009). According to Halpern (2014) critical thinking is the use of cognitive skills or strategies that are likely to improve desired learning outcomes. The types of thoughts involved in it include solving problems, formulating conclusions, calculating possibilities, and making decisions (Halpern, 2014). Critical thinking is also defined as the ability to use ideas to think openly, collect, analyze, evaluate various information, and explain conclusions that are logically obtained (Moon, 2008). Facione (2015) states that critical thinking skills cover 6 aspects, namely analysis, inference, explanation, interpretation, evaluation, and self-regulation.
Based on the results of the preliminary study analysis that has been carried out in three high schools in Ponorogo, Indonesia, it showed that students' critical thinking skills are in the medium-low category. This is consistent with the results of research Utami et al. (2018) in one of the High Schools in Central Java, Indonesia, which showed that most students have weak or low critical thinking skills. Harjo et al. (2019) also revealed that students' critical thinking skills in several schools in Indonesia are still low.

Based on the results of observations, students were more dominant using Student Worksheets (LKS) when learning activities take place. LKS can assist students in learning material, but it is not optimal enough to develop critical thinking skills. Meanwhile, the results of interviews with teachers revealed that students were less enthusiastic about chemistry lessons when learning was only done through listening activities and working on problems. Students will be more enthusiastic when learning is done through experiments and activities that involve student activity.

Thus, students need innovative, effective and efficient learning models to practice critical thinking (Perdana et al., 2019). Learning activities should ideally be adapted to $21^{\text {st }}$ century learning that requires students to have skills in problem solving, critical thinking, collaboration, communication, and creativity. Learning activities undertaken should be student-centered learning. One of the student-centered learning is guided discovery (Makoolati et al., 2015).

According to Bruner in Mayer (2004), on guided discovery-based learning, students are given problems and the teacher gives instructions, direction, feedback, and examples 
Effectiveness of Guided Discovery Based Thermochemistry Module to Train Critical Thinking Skills Based on Gender Differences

to guide students in solving problems. Bruner points out that every individual has a willingness to learn and this must be used in activities in such a way as to increase curiosity and direct students to learn and find knowledge.

Guided discovery-based learning emphasizes the active role of students in building concepts based on learning experiences through teacher guidance. Thus, student learning activities will be more meaningful and students can apply their knowledge in a broader context. The guided discovery syntax includes stimulation, problem identification, collecting data, analyzing data, verifying, and generalizing (Syah, 2014).

Guided discovery application in learning activities can improve student chemistry learning outcomes (Fatokun and Eniayeju, 2014). Therefore, guided discovery has a great opportunity to increase students' understanding of complex chemical materials, such as thermochemistry. Thermochemistry is one of the topics of chemistry that is considered difficult and abstract. This is because thermochemistry topic requires an understanding of concepts and algorithmics. Besides thermochemistry requires several concepts such as chemical reaction equations, stoichiometry, and hydrocarbons.

Guided discovery implementation will be carried out well if it is supported by competence of educators and the availability of modules in accordance with the guided discovery syntax. The development of modules is suitable as alternative teaching material to measure students' particular abilities through constructivist learning strategies (Rufii, 2015). The use of modules that are equipped with instructions can optimize the teacher's role as a facilitator and provide students opportunities for meaningful learning
(Wulandari et al., 2018). Guided discoverybased modules can help students understand concepts because students are guided in stages in finding concepts they learn and solving problems.

In addition to learning models or learning strategies and modules, in previous studies gender was also often associated with empowering critical thinking. Gender is a term for categorizing the sexes, male and female. Critical thinking skills related to gender differences are based on memory, language skills, and problem solving skills (Perdana et al., 2019). According to Fetalvero (2017) and Perdana, et al. (2019) gender differences influence the different ways of solving chemical problems between male and female students. Male and female students have different perspectives in describing the idea. Fetalvero (2017) states that in addition to gender differences, solving chemical problems is also influenced by experience and education. Based on this explanation, this study aimed to determine the effectiveness of guided discovery-based thermochemistry modules to train critical thinking skills based on gender differences.

\section{RESEARCH METHOD}

This study used a quasi-experimental method with one group pretest-posttest design. The research began by providing a pretest of critical thinking skills, then learning with guided discovery based modules, and at the end of the meeting the posttest of critical thinking skills was given.

\subsection{Research Subject}

The subjects of this study consisted of 96 students of class $\mathrm{XI}$ in the natural sciences program from three schools in Ponorogo, Indonesia. This study used one school for each category, namely high, medium and low 
Effectiveness of Guided Discovery Based Thermochemistry Module to Train Critical Thinking Skills Based on Gender Differences

categories. Determination of the categories of the three schools based on the average value of the 2016/2017 and 2017/2018 academic year national exams. The research subjects in the high school category consisted of 29 female and 7 male stuudents, the medium school category consisted of 28 female and 7 male students, and the low category school consisted of 19 female and 6 male students. There were no specific criteria in determining the number of female and male students in each school.

\subsection{Data Analysis Techniques}

The data analysis technique used an independent T test with SPSS 21 software to determine whether there were differences in the critical thinking skills of male and female students after the implementation of guided discovery-based thermochemistry modules. In addition, to measure the magnitude of the increase in students' critical thinking skills the normality of the gain score ( $\mathrm{N}$-gain) on each indicator of critical thinking. Determination of the $\mathrm{N}$-gain value using the following equation.

$$
g=\frac{\text { postest score }- \text { pretest score }}{\text { maxsimum score }- \text { pretest score }}
$$

\subsection{Description of Research Modules and Instruments}

The module used in the study is a guided discovery based print module on thermochemistry topic. The developed module consists of three main parts, namely the introduction, core, and closing. The introduction consists of the cover, preface, instructions for using the module, table of contents, basic competence and indicators of competency achievement, and concept maps. The core section contains thermochemistry topic, which is specific to the exothermic, endothermic, and calorimetric reaction sections. The main material is divided into two learning activities.
The module was developed based on guided discovery syntax and indicators of critical thinking. The explanation of each guided discovery stage in the module was explained as follows: (1) the stimulation stage was presented thermochemistry phenomena or facts related to daily life, (2) the problem identification stage, students were guided to determine the formulation of the problem in accordance with the topic of the activity learning, (3) data collection stage, students were asked to conduct experiments based on the instructions presented in the module, (4) data processing stages, students were guided to answer questions that can lead to the correct concepts through group discussion activities, (5) verification stage that is students were asked by students conduct an assessment or verification of the results of data analysis of the correct concept and answer the problem formulation, (6) generalization stage, students made conclusions from the concepts they learn.

At the end of each learning activity, a contextual problem was presented which aimed to develop student understanding. In addition to subject matter, this module was also equipped with sample questions, practice questions, chemical information, and evaluation questions. The last part of the module was the concluding part that includes a bibliography and glossary. A series of guided discovery-based learning activities aim to build students' concepts through the experience of their learning activities.

The guided discovery module and the critical thinking questions instrument used in the study were validated by 9 experts through focus group discussion (FGD) activities. The pretest and posttest instruments were developed in accordance with the indicators of critical thinking according to Facione (2015), which included analysis, inference, 
explanation, interpretation, and evaluation. One example problem to measure critical thinking skills in the evaluation indicators is presented in Table 1.

Table 1. Example of Question Points on Evaluation Indicators

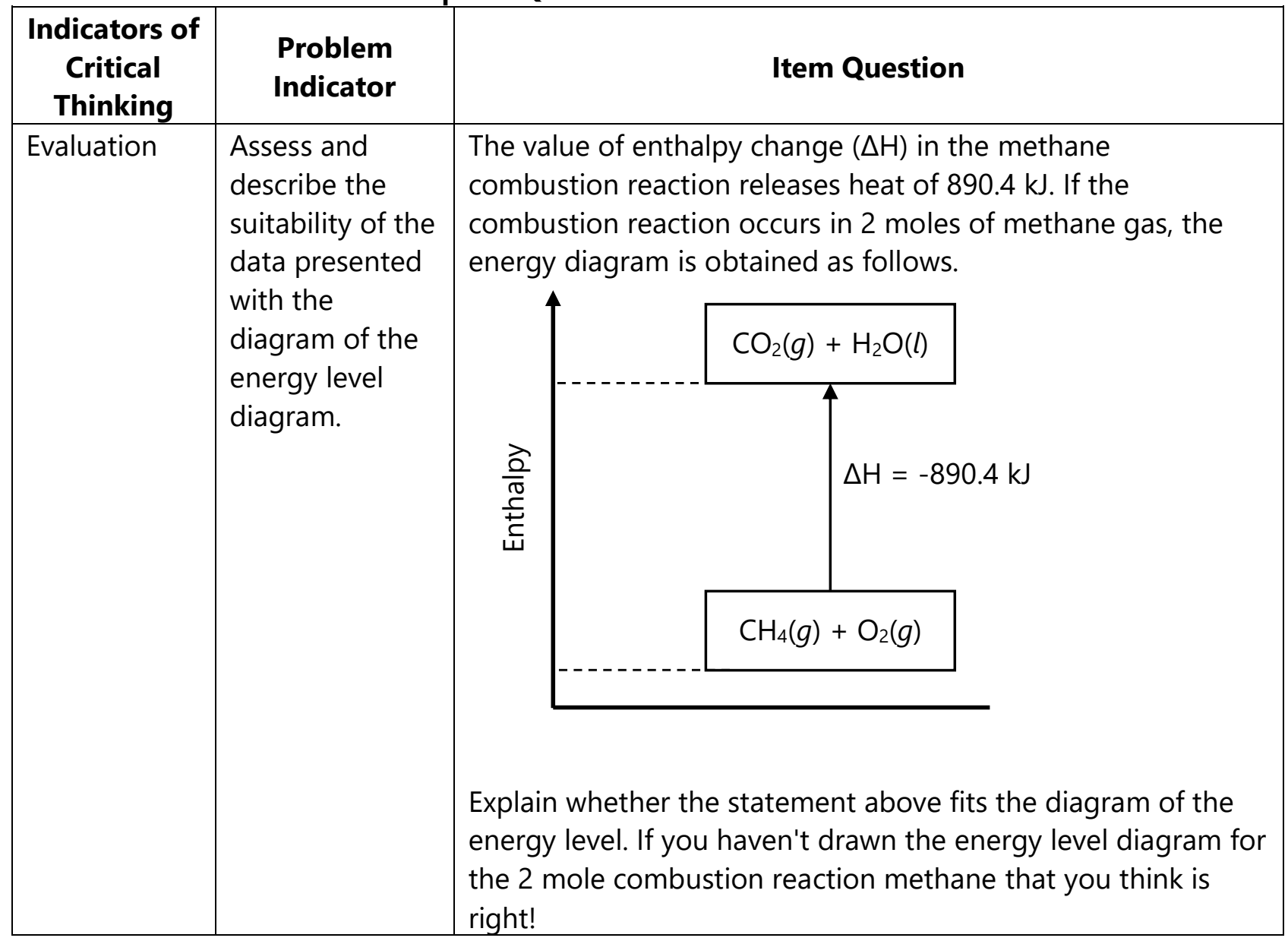

\section{RESULT AND DISCUSSION}

This study presented the effectiveness of the guided discovery-based module in training students' critical thinking skills, and the differences in critical thinking skills of male and female students. A description of critical thinking skills data is presented in Table 2.

$\mathrm{N}$-gain is used to find out the results of critical thinking test. Table 2 shows that the highest $\mathrm{N}$-gain was found in female students in high school categories. A positive $\mathrm{N}$-gain indicates that the posttest value is greater than the pretest value. The increase in critical thinking test results indicates that the implementation of guided discovery-based thermochemistry modules is effective in improving critical thinking skills. The results obtained are in line with several other studies which state that there are significant differences between students' pretest and posttest scores after using the guided discovery-based module (Perwitasari and Djukri, 2018; Robi et al., 2018; Yerimadesi et al., 2018). Other studies mention that the use of modules based on constructivism learning theory can improve students' critical thinking skills (Firdaus et al., 2015). 
Effectiveness of Guided Discovery Based Thermochemistry Module to Train Critical Thinking Skills Based on Gender Differences

Table 2. Description of the $\mathbf{N}$-Gain Value of Critical Thinking Skills Based on Gender Differences

\begin{tabular}{|l|l|c|c|c|}
\hline \multicolumn{2}{|c|}{} & N & $\begin{array}{c}\text { Average } \\
\text { N-gain }\end{array}$ & $\begin{array}{c}\text { Std. } \\
\text { Deviation }\end{array}$ \\
\hline $\begin{array}{l}\text { High } \\
\text { school } \\
\text { category }\end{array}$ & Male & 7 & 0.5143 & 0.08923 \\
\cline { 2 - 5 } & Female & 29 & 0.6362 & 0.14306 \\
\hline $\begin{array}{l}\text { Medium } \\
\text { school } \\
\text { category }\end{array}$ & Male & 7 & 0.5271 & 0.08159 \\
\cline { 2 - 5 } & Female & 28 & 0.5746 & 0.08338 \\
\hline $\begin{array}{l}\text { Low } \\
\text { school } \\
\text { category }\end{array}$ & Male & 6 & 0.5050 & 0.07120 \\
\cline { 2 - 5 } & Female & 19 & 0.5463 & 0.08200 \\
\hline
\end{tabular}

The use of modules can make learning activities in the class be directed so that the classroom atmosphere becomes more conducive. Modules are not only used as a learning guide, but are also used as a solution to stimulate students' critical thinking (Situmorang and Handayani. 2017).

The effectiveness test of the module can be seen based on the increase in student scores from pretest to posttest. Each pretest and posttest score from all school categories was grouped according to gender. Then an independent $\mathrm{T}$ test was performed on the $\mathrm{N}$ gain value with the following hypothesis provisions.

$\mathrm{H}_{0}=$ the average $\mathrm{N}$-gain value of female students no different from male students.

$\mathrm{H}_{1}=$ average value of $\mathrm{N}$-gain for female students different from male students.

The results of the independent $T$ test are presented in Table 3. Based on the analysis of Table 3 it can be seen that the calculated $T$ count from the independent $T$ test in the high school category is 2.142 with a T table of 2.032 . Thus the results of the $T$ test in high school category can be written $-2,142<-2,032(-T$ count $<-T$ table) or $2.142>2.032$ ( $\mathrm{T}$ count $>\mathrm{T}$ table). Based on these results it showed that $\mathrm{H}_{0}$ is rejected and $\mathrm{H}_{1}$ is accepted. Thus, there are differences in the average $\mathrm{N}$-gain value of female students with male students in high school categories.

Table 3. Result of $\mathbf{T}$ Test Analysis (N-gain Female-Male Students)

\begin{tabular}{|l|c|c|c|c|}
\hline & T & df & $\begin{array}{c}\text { Main } \\
\text { Differences }\end{array}$ & $\begin{array}{c}\text { Sig. } \\
\mathbf{( 2 -} \\
\text { tailed) }\end{array}$ \\
\hline $\begin{array}{l}\text { High } \\
\text { school } \\
\text { category }\end{array}$ & 2,142 & 34 & 0.12192 & 0.039 \\
\hline $\begin{array}{l}\text { Medium } \\
\text { school } \\
\text { category }\end{array}$ & 1,353 & 33 & 0.04750 & .185 \\
\hline $\begin{array}{l}\text { Low } \\
\text { school } \\
\text { category }\end{array}$ & 1,106 & 23 & 0.04132 & 0.280 \\
\hline
\end{tabular}

A positive T-count (2.142) indicated that the $\mathrm{N}$-gain value of female students is higher than the $\mathrm{N}$-gain value of male students. It means that the increase in the pretest-posttest score is higher for female students. It indicates that the critical thinking skills of female students are better than male students. The results of this study are consistent with other studies which state that women's critical thinking skills are better than men's (Perdana et al., 2019; Mawaddah et al., 2018; Mahanal et al., 2017). It is influenced by the initial ability of students who become the basic capital in critical thinking (Fuad, 2017). In addition, female students are better at processing textual information (Yang, 2016). Male students generally have more complex problems in learning, especially in chemistry, than female students (Dori et al., 2018; Situmorang et al., 2018).

High or low critical thinking skills of a person can be influenced by the syntactic learning model, environment, age, experience differences, gender differences based on memory, language skills, and problem solving skills (Perdana et al., 2019). In addition, the use of learning methods or models that can stimulate students' critical thinking skills can 
Effectiveness of Guided Discovery Based Thermochemistry Module to Train Critical Thinking Skills Based on Gender Differences

also influence students' critical thinking skills (Wan and Lee, 2017). In high school categories, female students are more active and enthusiastic during the learning activities, so this is also a supporting factor that causes the value of critical thinking abilities of female students to be higher than that of male students.

Meanwhile, the calculated $\mathrm{T}$ count and $\mathrm{T}$ table from the independent $T$ test in the medium category schools were 1.353 and 2.034, respectively. $T$ test results in the medium category can be written $-2,034<1,353<2,034$ (-T table $<\mathrm{T}$ count $<\mathrm{T}$ table), so $\mathrm{H}_{0}$ is accepted. It showed that in the medium category the average $\mathrm{N}$-gain for female students was no different from that of male students. In low category schools, the calculated T count and T table from the $T$ test were respectively 1.106 and 2.068. $T$ test results in low category schools can be written $-2,068<1,106<2,068$ ( $-\mathrm{T}$ table $<\mathrm{T}$ count $<\mathrm{T}$ table). So, the average $\mathrm{N}$-gain value of female and male students in low category schools is no different.

Based on the results of T-test analysis in the medium and low category schools showed that the increase in the pretest-posttest scores of female and male students was not significantly different. The results of this study are consistent with other studies which state that gender differences do not affect students' critical thinking skills (Fernandi et al., 2018; Fitriani et al, 2019; Irwing and Lynn, 2005).

According to Irwing and Lynn (2005), basically there is no difference in the core of intelligence or common factors between men and women. The difference only occurs in specific cognitive abilities, such as men are better quantitatively and women are better verbally (Verawati et al., 2010). In the medium and low category schools, both female and male students have almost the same response during the learning activities. According to Fernandi et al. (2018), gender has no role in influencing critical thinking skills. However, because critical thinking is a measurable ability, of course this critical thinking ability is influenced by the initial abilities possessed by each student.

The results of the analysis of each indicator of critical thinking between female and male students in high school categories can be seen in Figure 1.

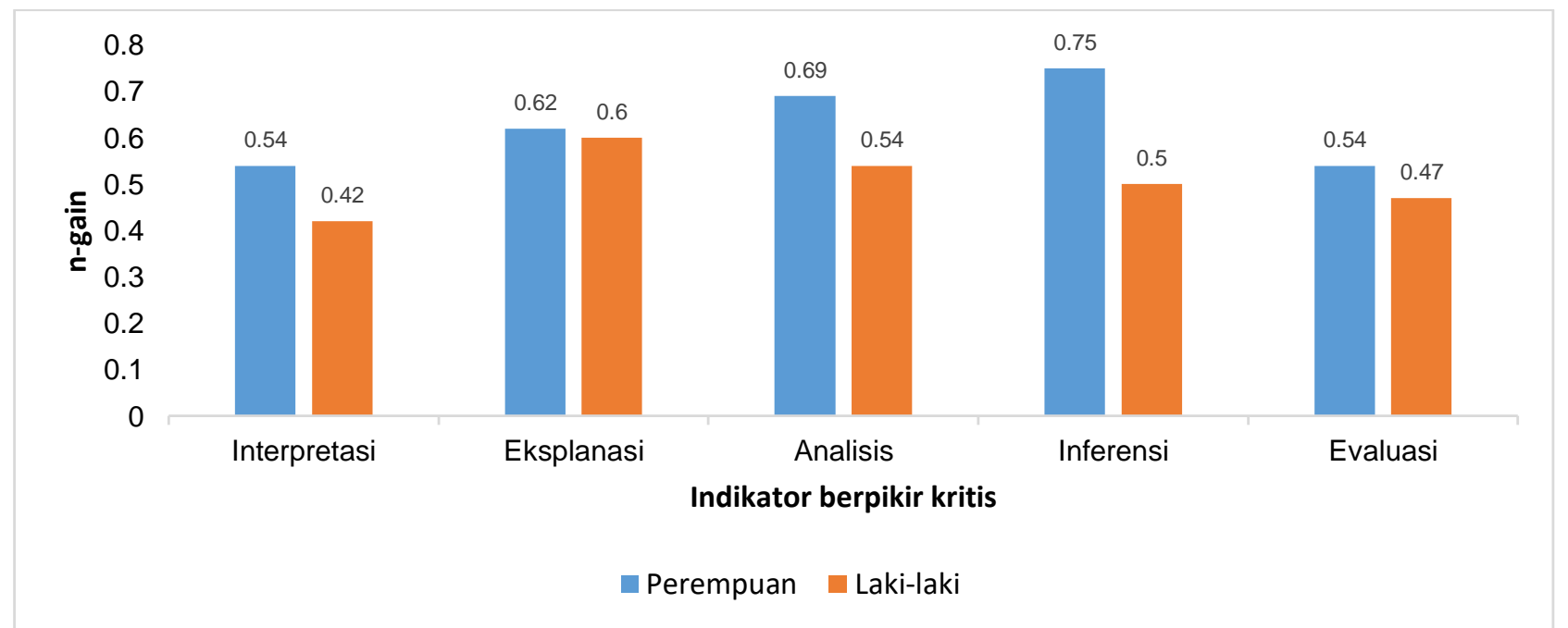

Figure 1. The Results of the N-Gain Values Respectively Indicator of Critical Thinking from School High Category 
Effectiveness of Guided Discovery Based Thermochemistry Module to Train Critical Thinking Skills Based on Gender Differences

In high school category, N-gain for female students was higher than male students for all indicators of critical thinking. In accordance with research Suardana et al. (2018) which states that the value of critical thinking skills of female students which includes interpretation, analysis, explanation, inference, evaluation, and self-regulation is higher than the value of male students. According to Perdana et al. (2019), women are also considered better at identifying problems, giving statements and questions, explaining concepts, giving reasons and opinions, and the ability to make conclusions than men.

The highest $\mathrm{N}$-gain for female students was in the inference indicator, it was 0.75 , which means an increase in the pretest-posttest is in the high category. Indicators of interpretation and evaluation became the lowest critical

thinking skills for female students in high school categories. The highest $\mathrm{N}$-gain for male students was in the explanatory indicator, it was 0.60. Meanwhile the indicators of interpretation and evaluation were the lowest critical thinking skills for male students in high school categories.

Inference indicator is an indicator that has the most significant difference in $\mathrm{N}$-gain value compared to the others. So in high school categories, significant differences in $\mathrm{N}$-gain values between female and male students are found in indicators of inference, analysis, and interpretation.

The results of the analysis of each indicator of critical thinking between female and male students in the medium category school can be seen in Figure 2.

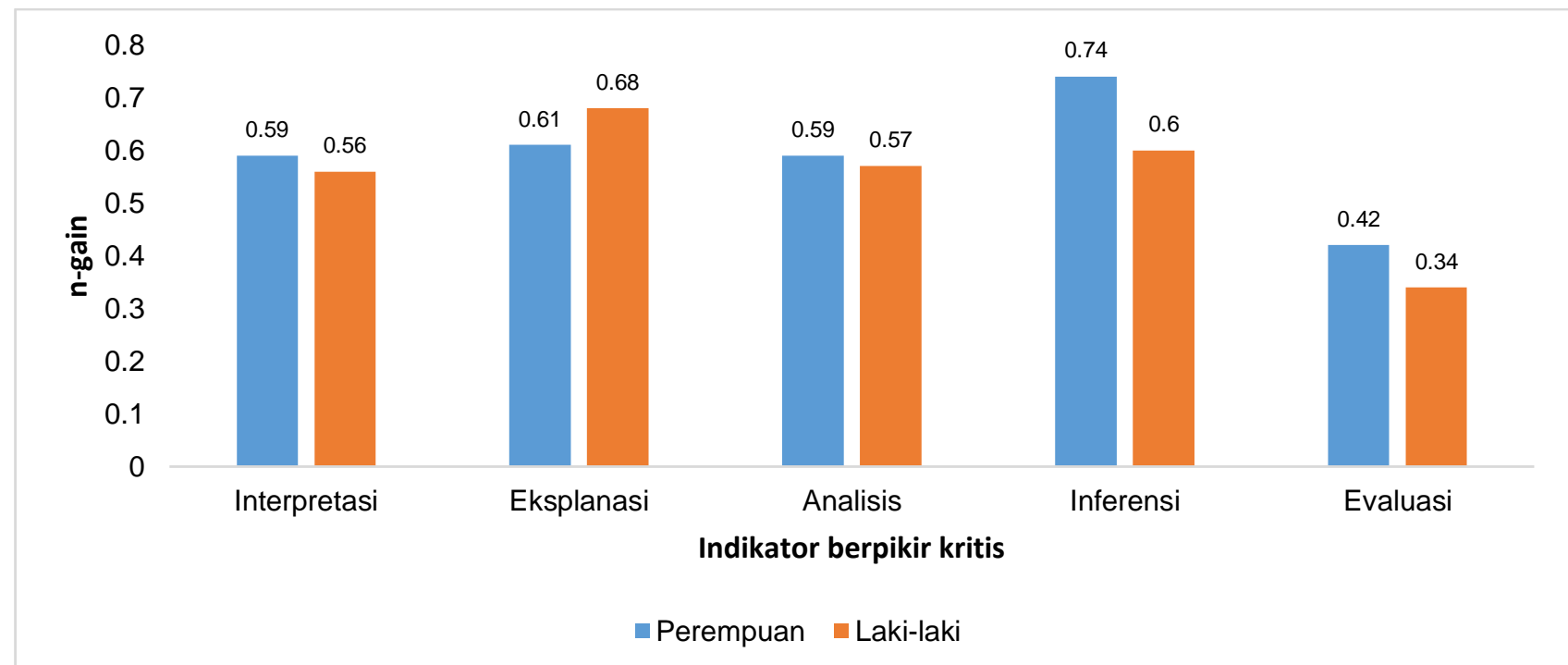

Figure 2. The Results of the N-Gain Values Respectively Indicator of Critical Thinking from School Medium Category

$\mathrm{N}$-gain for female and male students in the medium category was not significantly different. The indicator that had the highest $\mathrm{n}$ gain difference is the inference indicator, which has an $\mathrm{N}$-gain difference of 0.14 . The indicators of interpretation, analysis, inference, and evaluation of the $\mathrm{N}$-gain value of female students are higher than that of male students. Whereas in the explanatory indicator the $\mathrm{N}$ gain value of male students is higher than that of women. The increase in the pretest-posttest value of male students in the medium category was the highest in the explanatory indicator. Meanwhile, the highest increase in the pretest- 
posttest of female students in the medium category is found in the inference indicator.
The results of the analysis of each indicator of critical thinking between female and male students in low category schools can be seen in Figure 3.

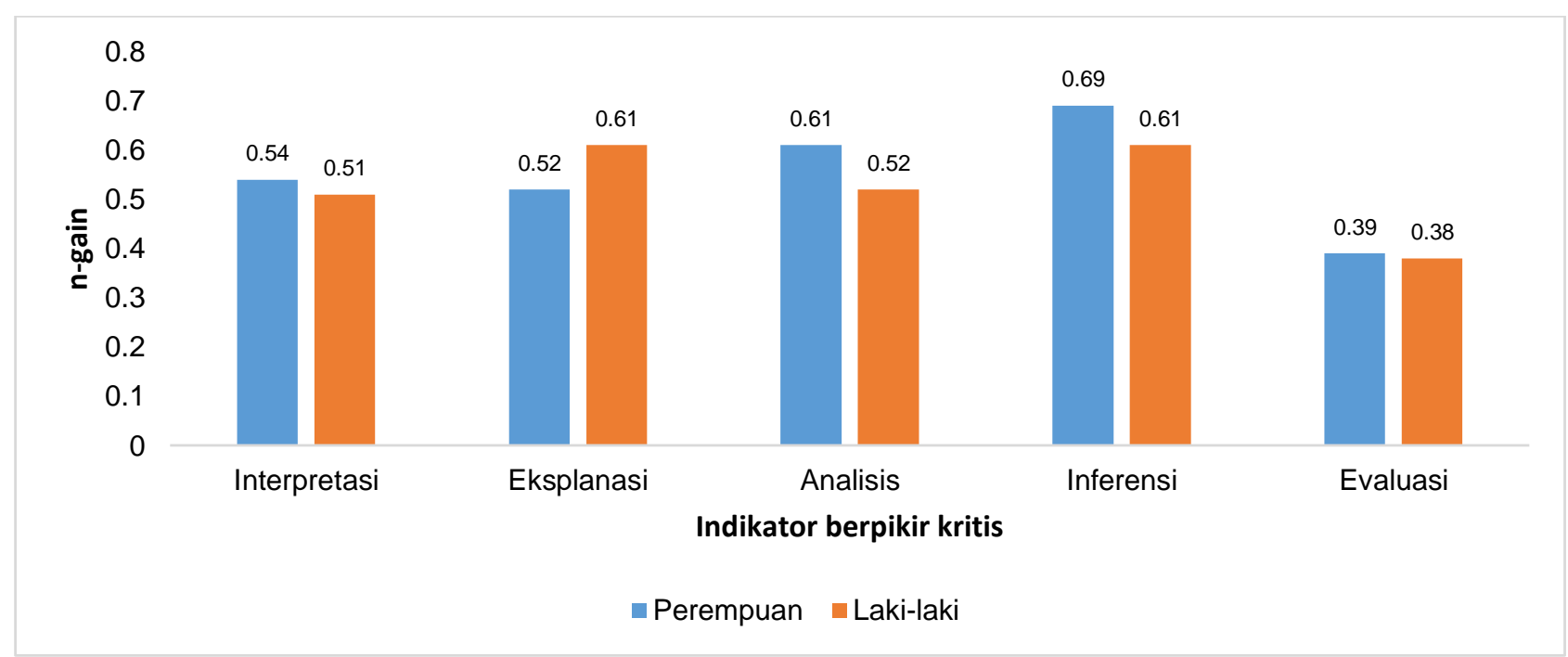

Figure 3. The Results of Each N-Gain Value Indicator of Critical Thinking from School Low Category

$\mathrm{N}$-gain for female and male students in low school categories was not significantly different. Indicators that have the highest $\mathrm{N}$ gain difference were explanations and analysis indicators. In low category schools, the indicators of interpretation, analysis, inference, and evaluation showed higher $\mathrm{N}$-gain scores for female students than for men. Meanwhile, the $\mathrm{N}$-gain indicator for explanation of male students was higher than that of female students. The highest increase in the pretestposttest of male students in low category schools was found in the explanatory and inference indicators. Meanwhile, the highest increase in pretest-posttest scores for female students is in the inference indicator.

Based on the $\mathrm{N}$-gain analysis of each indicator in the three schools, female students tended to have the highest increase in the pretestposttest in the inference indicator. Male students in all three schools had the highest increase in pretest-posttest scores on explanatory indicators. Evaluation indicators became indicators that have the lowest $\mathrm{N}$-gain in high, medium, and low school categories. It is in accordance with research Basri et al. (2019) which states that evaluation is one of the lowest critical thinking skills.

\section{CONCLUSION}

The results showed that the implementation of guided discovery-based thermochemistry modules was effective in developing critical thinking skills of female and male students because there were significant differences in the pretest and posttest scores. The average increase in student grades or $\mathrm{N}$-gain values of 0.5050 to 0.6362 . Thus, guided discoverybased thermochemistry modules are effectively applied to high, medium and low category schools.

Result in $\mathrm{T}$ test in high category schools obtained the value of T count $>\mathrm{T}$ table $(2.142$ $>2.032$ ). Based on the results of the $T$ test shows that in high school category critical thinking skills female students was different than male students. Positive $T$ count shows 
that the critical thinking skills of female students are better than male students.

Meanwhile, the calculated $\mathrm{T}$ count and $\mathrm{T}$ tables in the medium category were 1.353 and 2.034, respectively. $T$ count and $T$ tables in the low category schools respectively by 1.106 and 2.068. Analysis of $\mathrm{T}$ test results in medium and low school categories can be written - $T$ table $<\mathrm{T}$ count < $\mathrm{T}$ table, which showed no significant difference between the critical thinking skills of female and male students after the implementation of guided discoverybased thermochemistry modules.

The highest critical sub-thinking skills of female students in all three schools was inference, while the highest critical subthinking skills of male students in all three schools was explanations. Evaluation is the lowest sub-skill of female and male students in high, medium, and low school categories.

Thus, the results of this study can be used as a basis for discussion and further research related to the effectiveness of guided discovery-based modules in developing critical thinking skills in other chemical topics. In addition, this research provides a reference to educators that the need for more innovative learning activities to explore the potential of students. 


\section{REFERENCES}

Basri, H., Purwanto, As'ari, A. R., \& Sisworo. (2019). Investigating Critical Thinking Skill of Junior High School in Solving Mathematical Problem. International Journal of Instruction, 12(2), 745-758

Brown, B. (2015). Twenty First Century Skills: A Bermuda College Perspective. Voice in Education, 1, 58-64.

Changwong, K., Sukkamart, A., \& Sisan, B. (2018). Critical Thinking Skill Development: Analysis Of A New Learning Management Model For Thai High Schools. Journal of International Studies, 11(2), 37-48.

Dori, Y. J., Zohar, A., Fischer-Shachor, D., Kohan-Mass, J., \& Carmi, M. (2018). Gender-Fair Assessment of Young Gifted Students' Scientific Thinking Skills. International Journal of Science Education, 40(6), 595-620.

Facione, P. A. (2015). Critical Thinking: What It Is and Why It Counts. Insight Assessment.

Fatokun, K., \& Eniayeju, P. (2014). The Effect of Concept Mapping-Guided discovery Integrated Teaching Approach on Chemistry Students' Achievement and Retention. Educational Research and Reviews, 9(22), 1218-1223.

Fernandi, R, A, U, I., Firman, H., \& Rusyati, L. (2018). The Relationship Among Critical Thinking Skill Measured By Science Virtual Test, Gender, And Motivation In $9^{\text {th }}$ Grade Students. International Seminar of Mathematics, Science and Computer Science Education, Journal of Physics: Conf. Series.

Effectiveness of Guided Discovery Based Thermochemistry Module to Train Critical Thinking Skills Based on Gender Differences

Fetalvero, E. G. (2017). Consensus-Based Education: Its Effect on College Students' Achievement in Bioenergetics as Moderated by Gender and Learning Styles. Journal of Baltic Science Education, 16(4), 533-548.

Firdaus, F., Kailani, I., Bakar, M. N. B., \& Bakry, B. (2015). Developing Critical Thinking Skills of Students in Mathematics Learning. Journal of Education and Learning, 9(3), 226-236.

Fitriani, H., Asy'ari, M., Zubaidah, S., \& Mahanal, S. (2019). Exploring the prospective teachers' critical thinking and critical analysis skills. Jurnal Pendidikan IPA Indonesia, 8(3), 379-390.

Fuad, N. M., Zubaidah, S., Mahanal, S., \& Suarsini, E. (2017). Improving Junior High Schools' Critical Thinking Skills Based on Test Three Different Models of Learning. International Journal of Instruction, 10(1), 101-116.

Halpern, D. F. (2014). Thought And Knowledge 5th Edition. New York \& London: Psychology Press.

Harjo, B., Kartowagiran, B., \& Mahmudi, A. (2019). Development of Critical Thinking Skill Instruments on Mathematical Learning High School. International Journal of Instruction, 12(4), 149-166.

Irwing, P., \& Lynn, R. (2005). Sex Differences in Means And Variability on The Progressive Matrices In University Students: A Meta-Analysis. British Journal Of Psychology, 96(4), 505-524.

Jacob, S. M. (2012). Mathematical Achievement And Critical Thinking Skills In Asynchronous Discussion Forums. 
Effectiveness of Guided Discovery Based Thermochemistry Module to Train Critical Thinking Skills Based on Gender Differences

Procedia - Social and Behavioral Sciences, 31, 800-804.

Mahanal, S., Tendrita, M., Ramadhan, F., Ismirawati, N., \& Zubaidah, S. (2017). The Analysis of Students' Critical Thinking Skills on Biology Subject. Anatolian Journal of Instruction, 2(2), 21-39.

Makoolati, N., Amini, M., Raisi, H., Yazdani, S., \& Razeghi, A. V. (2015). The Effectiveness Of Guided Discovery Learning On The Learning And Satisfaction Of Nursing Students. Hormozgan Medical Journal, 18(6), 490-496.

Mawaddah, Ahmad, A., \& Duskri, M. (2018). Gender Differences of Mathematical Critical Thinking Skills Of Secondary School Students. The 6th South East Asia Design Research International Conference, Journal of Physics: Conf. Series.

Mayer, R. E. (2004). Should There Be a ThreeStrikes Rule Against Pure Discovery Learning? The Case for Guided Methods of Instruction. American Psychologist, 59(1), 14-19.

Moon, J. (2008). Critical Thinking: An Exploration of Theory And Practice. London \& New York: Routledge.

Moore, B. N., \& Parker, R. (2009). Critical Thinking. Boston, MA: McGraw-Hill.

Perdana, R., Budiyono, Sajidan, \& Sukarmin. (2019). Analysis of Student Critical and Creative Thinking (CCT) Skills on Chemistry: A Study of Gender Differences. Journal of Educational and Social Research, 9(4), 43-52.

Perwitasari, N., \& Djukri, D. (2018). Developing
Thematic-Integrated Module Based On Guided Discovery To Improve Critical Thinking And Student Science Attitude. Jurnal Prima Edukasia, 6(1), 44-55.

Robi, A. A., Hobri, \& Dafik. (2018). The Analysis of Critical Thinking Skill of Version P21 in Solving the Problems of Two Dimensional Arithmetic Derived from the Implementation of Guided discovery Learning. International Journal of Scientific Research and Management, 6(1), 6-13.

Rufii, R. (2015). Developing Module on Constructivist Learning Strategies to Promote Students' Independence and Performance. International Journal of Education, 7(1), 18-28.

Situmorang, A., \& Handayani, S. (2017). Effectiveness Module Development: Implementation on Learning History. The International Journal of Social Sciences and Humanities Invention, 4(8), 38563859.

Situmorang, M., Sinaga, M., Purba, J., Daulay, S. I., Simorangkir, M., Sitorus, M., \& Sudrajat, A. (2018). Implementation of Innovative Chemistry Learning Material with Guided Tasks to Improve Students' Competence. Journal of Baltic Science Education, 17(4), 535-550.

Suardana, I. Nyoman, Redhana, I. Wayan, Sudiatmika, A. A. I. A. R., \&Selamat, I. Nyoman. (2018). Students' Critical Thinking Skills in Chemistry Learning Using Local Culture-Based 7E Learning Cycle Model. International Journal of Instruction, 17(2), 399-412.

Syah, M. (2014). Psikologi Pendidikan dengan Pendekatan Baru. Bandung: PT Remaja 
Effectiveness of Guided Discovery Based Thermochemistry Module to Train Critical

Rosda Karya.

Tiruneh, D. T., De Cock, M., Weldeslassie, A. G., Elen, J., \& Janssen, R. (2017). Measuring Critical Thinking in Physics: Development and Validation of a Critical Thinking Test in Electricity and Magnetism. International Journal of Science and Mathematics Education, 15(4), 663-682.

Utami, B., Saputro, S., Ashadi, Masykuri, M., Probosari, R. M., \& Sutanto, A. (2018). Students Critical Thinking Skills Profile: Constructing Best Strategy in Learning Chemistry. International Journal of Pedagogy and Teacher Education, 2, 7176.

Verawati, Arifina, S. R., Idrisa, R., \& Hamid, N. A. A. (2010). Gender Analysis of MyCT (Malaysian Critical Thinking) Instrument. Procedia - Social and Behavioral Sciences, 7(C), 70-76.

Vong, S. A., \& Kaewurai, W. (2017). Instructional Model Development To Enhance Critical Thinking And Critical Thinking Teaching Ability Of Trainee Students At Regional Teaching Training Center In Takeo Province, Cambodia. Kasetsart Journal of Social Sciences, 38(1), 88-95.

Wan, Z. H., \& Lee, J. C. K. (2017). Hong Kong Secondary School Students' Attitudes Towards Science: A Study of Structural Models and Gender Differences. International Journal of Science Education, 39(5), 507-527.

Wulandari, I. G. A. P. A., Sa'dijah, C., As'ari, A. R., \& Rahardjo, S. (2018). Modified Guided discovery Model: A Conceptual Framework for Designing Learning
Thinking Skills Based on Gender Differences

Model Using Guided discovery to Promote Student's Analytical Thinking Skills. 2nd International Conference on Statistics, Mathematics, Teaching, and Research, Journal of Physics: Conf. Series.

Yang, S. H. (2016). Conceptualizing Effective Feedback Practice Through An Online Community Of Inquiry. Computers \& Education, 94, 162-177.

Yerimadesi, Bayharti, Jannah, S. M., Lufri, Festiyed, \& Kiram, Y. (2018). Validity and Practitality of Acid-Base Module Based on Guided discovery Learning for Senior High School. International Conference on Mathematics, Science, Education and Technology (ICOMSET), Journal of Physics: Conf. Series. 